DOI: 10.46340/ephd.2020.6.1.19

\title{
Сергій Гулевський
}

Харківський національний університет імені В.Н.Каразіна, Україна

\section{КУЛЬТОВЕ ТЕЛЕБАЧЕННЯ \\ VS МЕЙНСТРИМ ТЕЛЕБАЧЕННЯ: \\ ФІЛОСОФСЬКЕ ОСМИСЛЕННЯ}

\author{
Serhii Hulevskyi \\ ORCID ID: https://orcid.org/0000-0002-9819-7432 \\ V.N. Karazin Kharkiv National University, Ukraine

\section{CULT TV VS. MAINSTREAM TELEVISION: PHILOSOPHICAL REFLECTION}

The article reveals the essential relationship between cult television and mainstream television. Cult television is seen as an analog of elitist culture in mass society and one of the important areas of artistic creativity in modern society. It has been revealed the communicative nature of the phenomenon of television, which is manifested, in particular, in the feedback between the audience of viewers and the creators of the television product. The analysis of television series revealed the complex nature of the interdependence of the audio and visual, the emotional and the rational components, the cult series, and the mainstream. Cult television is a means of empowering the development of both television series and television in general. The peculiarities of the functioning of television as a sign system have been clarified.

Keywords: TV series, media communication, cult television, mainstream television, audiences.

Філософський підхід до телебачення дає можливість розкрити цей феномен сучасної культури не лише у його автентичності та цілісності, але й у сукупності його сутнісних зв'язків - як тих, що поступово формуються і розкриваються все більшою мірою історично, так і тих, які пов'язують телебачення з іншими феноменами сучасної культури як складної, але все ж єдиної символічної системи. Філософське питання полягає не лише в тому, якого роду знаки утворюють цю систему (таке питання належить більшою мірою сфері семіотики як науки про знаки і знакові системи), але і в тому, як ці знаки утворюються, функціонують та розвиваються у суспільстві, тобто - питання прагматики. I тут можна простежити дві традиції, які народжуються у XX столітті, як засвідчує американський дослідник Філіп Селзнік'. Згідно першої масове суспільство є ірраціональним у своїй суті, соціальними масами рухають інстинкти, на відміну від до-масових суспільств, еліта у ньому втрачає свою провідну організуючу роль - одним словом, масове суспільство є злом, але злом неминучим, яке просто треба пережити, і воно якимось чином саме має переродитися у щось інше. Таку традицію свого часу заснували праці прихильників теорії еліт - зокрема, іспанського філософа Хосе Ортеги-іГассета $^{2}$ і німецького філософа Карла Маннгейма ${ }^{3}$. Згодом, схожу позицію захищатимуть німецькі теоретики Макс Хоркхаймер і Теодор Адорно у своїй критиці Просвітництва і масового суспільства як його закономірного продукту ${ }^{4}$. Згідно їхніх поглядів, лише еліта здатна творити справжні культурні цінності, тоді як соціальні маси послуговуються ерзацами культурних цінностей, по-справжньому культури не мають, а відтворюють бездумно псевдо-культуру, маси мають лише сліпі бажання. Іншу традицію представляють праці філософів, які вважають, що час еліт пішов у минуле безповоротно, а сучасне суспільство з вертикально і ієрархічно побудованого перетворилося на горизонтально диференційоване. Різною $\epsilon$ лише оцінка якості соціальної інтеграції у цьому високо

\footnotetext{
${ }^{1}$ Selznick, P. (1951). Institutional Vulnerability in Mass Society. American Journal of Sociology, 56, 320-331.

${ }^{2}$ Ортега-и-Гассет, Х. (1997). Восстание масс. Ортега-и-Гассет Х. Избранные трудыл. Москва: Весь мир, $43-163$.

${ }^{3}$ Манхейм, К. (2000). Избранное. Социология культуры. Москва - СПб: Университетская книга, 501.

${ }^{4}$ Хоркхаймер, М., Адорно, Т. (1997). Диалектика просвещеения: Философские фрагментыл. Москва-СПб:

Медиум. Ювента, 311.
} 
диференційованому суспільстві- багато хто з антиелітаристів поділяє песимістичну оцінку перспектив самоорганізації масового суспільства, яку дають прихильники теорії еліт. Такі погляди можна зустріти, зокрема, у Еріха Фромма, який аналізує людину маси під кутом зору фрейдомарксизму, виявляючи в ній як відчуження, так і садомазохістичні прояви ${ }^{1}$. На наш погляд, більш виважену позицію пропонує німецький філософ Карл Ясперс, який вважає, що у сучасному суспільстві, можливо, і немає яскраво виражених еліт, але завжди є можливість для духовного розвитку творчої особистості, яка буде йти проти течії масової культури, але розвиток самої цієї культури буде критично залежати від здобутків цих творчих особистостей - саме їхні наукові відкриття і витвори мистецтва лягають в основу того, що згодом буде споживати соціальна маса ${ }^{2}$. Телебачення, безумовно, якраз і $є$ ареною, на якій зустрічаються у своєму змаганні і взаємному впливі масова і елітарна культура, причому як у першій, так і у другій, на наше переконання, можна зустріти як шедеври у своєму роді, так і доволі посередні зразки.

3 моменту виникнення, телебачення зазвичай збирало велику аудиторію, бо видовище прямої трансляції різноманітних подій, свідками яких начебто ставали глядачі, емоційно збуджувало та приносило задоволення. Проте з позицій інституціональної перспективи, як це аналізує Кетрін Джонсон, концепт культового телебачення, насамперед, телевізійного серіалу або телевізійної драми, сформувався лише у 80-тих роках двадцятого століття ${ }^{3}$ Телевізійний серіал, у будь-якому разі, доцільніше розглядати окремо від інших продуктів телебачення, оскільки це не просто технічна можливість медіа передавати аудіовізуальну інформацію, а щось значно більше. Телевізійний серіал це комплекс взаємодій між авторами, аудиторією, акторами, студією-виробником та естетичносмаковими примхами середовища, в якому здійснюється телемовлення. Тенденції останнього десятиліття показують, що телевізійний серіал не тільки витримує конкуренцію з кіноіндустрією, але й часом перевершує іiі, залучаючи у свої проєкти мегазірок, значні фінансові інвестиції та диверсифікуючи канали поширення продукту.

Метою нашої розвідки є з'ясувати місце культового телебачення у розвитку сучасного телебачення та масової культури на прикладі культового телесеріалу.

Культове телебачення як частина телемедіа простору жваво обговорюється науковцями, серед яких переважають теоретики з тих країн, де найбільше розвинута галузь телеіндустрії. За редакцією дослідниці кіно та телебачення Стейсі Ебботт вийшла збірка «The Cult TV Book», у якій представлено головні дискусійні блоки щодо явища культового телебачення, а саме: 1) дискусія навколо безпосереднього визначення змінної дефініції культового телебачення та його зв'язок з якісним телебаченням; 2) культові телесеріали як переосмислення конвенціальних основ телебачення та розсунення меж його наративів та стилістики; 3) особливості телевиробництва та складання сітки телемовлення і їх вплив на культове ТБ і 4) вивчення глядачів, нішевої аудиторії культових серіалів, так званого фандому ${ }^{4}$.

У згаданій збірці Роберта Пірсон, після розмірковувань про те, що будь-які визначення обмежують предмет дослідження, все ж таки запропонувала актуальну дефініцію, якою ми скористаємося, дещо адаптувавши до нашої термінології. Отже, у загальному сенсі, культовим вважається телесеріал (шоу), яке приваблює нішеву аудиторію, завдяки зверненню до символів чи

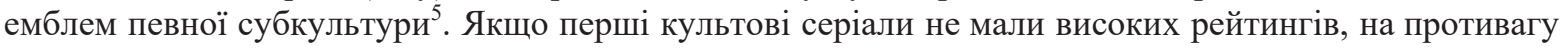
серіалам мейнстриму, насамперед, у жанрі вестерн, і трималися у сітці мовлення завдяки активності своїх прихильників, що очікували маніфестації суспільних проблем чи вузькоспеціалізованих інтелектуальних тем, то з часом ситуація змінилася. Як показано у дослідженні Серджіо Анджеліні та Майлза Буя культові серіали стали своєрідною протоплазмою, з якої виріс сучасний мейнстрим. Переломним, на їх думку, був серіал «Твін Пікс», який все ще залишався культовим у звичному розумінні, зі складними сюжетними розгалуженнями, напівнатяками, проте дав світу низку культових і водночас мейнстримових серіалів, які «замінили всі абразивні краї на більш звичні формати і

\footnotetext{
${ }^{1}$ Фромм, Э. (1999) Анатомия человеческой деструктивности. Минск: Попурри, 624.

2 Ясперс, К. (1991) Духовная ситуация времени. Ясперс К. Смысл и назначение истории. Москва: Политиздат, 288-418.

${ }^{3}$ Johnson, C. (2010). Cult TV and the Television Industry. The Cult TV Book. London, NY, 135.

${ }^{4}$ Abbot, S. (ed.) (2010). The Cult TV Book. London, New York: I.B. Tauris.

${ }^{5}$ Pearson, R. (2010). Observations on Cult Television. The Cult TV Book. London, NY, 7.
} 
сюжети» ${ }^{1}$. Мова йде, наприклад, про запозичення ідеї щодо агентів спецслужб, які спеціалізуються на паранормальних явищах для серіалу «Цілком таємно» (The X-Files) чи використання північної тихоокеанської природи у серіалі «Northern Exposure» (не транслювався в Україні). Додамо, що цей містичний природний ландшафт дуже органічно вписується у стилістику франшизи великого екрану «Сутінки», яка була розгорнута у такий собі міні серіал із п’яти епізодів. До речі, це заслуговує окремого аналізу- як принцип серійності поступово став вдалим маркетинговим ходом та організуючим підгрунтям для провідних медіа компаній.

Зрештою, Анджеліні та Буй констатували, що культовий серіал, що зародився як послання до певних груп населення (до нішевої аудиторії), зберігаючи гостру проблематику таку як гендерні питання, сексуальна орієнтація, соціально-расова дискримінація тощо, примножив кількість своїх шанувальників завдяки розкручуванню певної франшизи через різні медіа: книги, саундтреки, ігри та інше. Окрім збільшення прибуттів правовласників, це сприяло збільшенню глядацької аудиторії, яка вже не обмежувалася специфічним фандомом культового серіалу, що начебто призвело до того, що «поняття мейнстриму із захопленням було проголошено мертвим» ${ }^{2}$. Але не так швидко - як показує ретельніший аналіз телеконтенту та рейтингів серіалів сталося так, що культовий телесеріал просто перетворився на мейнстрим. Чи не найкращий аргумент цьому твердженню - серіал «Гра Престолів».

На жаль, відсутність розвинутої конкурентної деідеологізованої галузі телевиробництва на теренах радянської системи унеможливили еволюційний розвиток телесеріалу. Кінематограф ще може похвалитися десятком фільмів, наприклад, режисера Андрія Тарковського, які можуть претендувати на положення культового фільму у радянській культурі, проте телебачення - ні. Ті кроки, що почала здійснювати телеіндустрія останні десятки років демонструють відтворення, копіювання виробничих і творчих процесів, які відбуваються у країнах з розвинутою економікою. У більшості панує уявлення, що культовий культурний продукт - це щось дуже популярне $\mathrm{i}$ надзвичайно відоме. Але, як зауважує Метт Хіллс, тільки вибаглива та розумна аудиторія може отримати це послання, бо «є щось особливе, щось, принаймні, андеграундне або навіть трансгресивне щодо культових медіа, включаючи культове телебачення» ${ }^{3}$. Поняття культового телебачення та мейнстриму знаходяться у відношеннях бінарної опозиції, проте такої, що постійно переозначується, тому можливі трансформації статусу серіалів із культового до мейнстриму і навпаки. Але радянські і пострадянські телесеріали, у тому числі українського виробництва, займають позиції у кращому разі популярного явища культури - мейнстриму. У цьому контексті безперечно найбільш культовим мейнстримом можна вважати у радянський період «Сімнадцять миттєвостей весни». Окремо слід зазначити іноземні серіали, які почали транслювати по телебаченню ще у радянські часи, і які набули статусу культового мейнстриму завдяки своїй одиничності. До таких можна безумовно віднести низку бразильських та мексиканських серіалів «Рабиня Ізаура», «Багаті також плачуть». Згодом їх все більш упевнено почали заміщати їхні російські та українські адаптації - «Бідна Настя», «Кріпосна» (насправді, правильно казати кріпачка) тощо. Згодом, після розпаду СРСР, популярними стали, на жаль, серіали, що романтизують кримінальну сферу, зокрема, російські серіали «Бригада», «Бандитський Петербург», що виплекали ціле покоління з толерантним ставлення до псевдоестетики та псевдоетики бандитського світу. Доволі багато серіалів почало продукувати сучасне вітчизняне телебачення, причому деякі 3 них наближаються до статусу культових - наприклад, такі як «День народження буржуя», «Нюхач» або «Пес». Дає надію на новий етап розвитку українського телевиробництва новітній серіал «Спіймати Кайдаша» (канал СТБ), що створений за мотивами класичної повісті Івана Нечуя-Левицького. За короткий час прокату зібрав багато схвальних відгуків, проте чи стане культовим - покаже час.

Серед медіа-науковців переважає думка, що трансформація культового серіалу у мейнстрим повинна завдячувати як розвитку нових медіа-технологій телевізійного сигналу, так і особливостям текстуальності телевізійних серіалів, які завдяки своїй відкритості залишають багато простору для творчих фантазій шанувальників. На таких позиція стоїть, зокрема, Кетрін Джонсон, коли говорить про ефективні методи заохочення аудиторії через мережеві та цифрові медіа ${ }^{4}$, вже згаданий Метт

${ }^{1}$ Angelini, S., Booy, M. (2010). Members Only: Cult TV from Margins to Mainstream. The Cult TV Book. London, NY, 24.

${ }^{2}$ Ibid.

${ }^{3}$ Hills, M. (2010). Mainstream Cult. The Cult TV Book. London, NY, 67.

${ }^{4}$ Johnson, C. (2010) Cult TV and the Television Industry. The Cult TV Book. London, NY, 142-143. 
Хіллс, коли веде мову про культові медіа-тексти, Роберта Пірсон, коли підкреслює, що культове телебачення обслуговує не нішеву аудиторію, а «напружені інтерпретаційні практики <деякої> аудиторії» ${ }^{1}$ та інші. Погоджуючись 3 аналізом згаданих науковців, маємо зауважити, що існує ще одна характеристика телевізійного серіалу, яка, вочевидь, вплинула на трансформацію культового шоу у мейнстрим, тому заслуговує на висвітлення.

Насамперед, звернемося до ідеї, що пояснює, чому телесеріал культовим роблять глядачі, якщо точніше, то певна соціальна група як нішева аудиторія. Оскільки телебачення в цілому, а значить і його окремі частини як телесеріали, належать культурі постмодерну, то не дивно, що ідеї постмодерністів надають такі влучні й точні пояснювальні схеми явищам і процесам у сфері телемедіа. Одна із таких ідей - це ідея множинності Жиля Дельоза та Фелікса Гваттарі. На прикладі носія інформації книги, Дельоз та Гваттарі показали, що наратив, образ світу - це не прямий відбиток у нашій свідомості, а певна множинність. Він існує за посередництвом зовнішнього і в зовнішньому. Книга, на їх думку, являс собою маленьку літературну машину, яка знаходиться устосунках з іншими машинами: машиною війни, машиною любові, революційної машиною ${ }^{2}$, як спеціалізовані міні-спектаклі Гі Дебора 3 тотальним спектаклем ${ }^{3}$. Головне, на думку авторів, треба знати, до якої іншої машини можна і треба приєднувати літературну машину, щоб вона почала функціонувати, а також потрібна повна відсутність ідеології. Ця модель ідеально передає ситуацію з телевізійними серіалами. Справді, сам по собі телевізійний продукт тільки тоді здатен розкрити своє послання і стати культовим чи мейнстримом, коли існує адресат для цього послання, а у щойно згаданих термінах - машина, до якої треба під'єднати іншу машину - телесеріал. В цьому разі такою машиною-адресатом стає нішева аудиторія, яка складається з шанувальників (фандом) культового серіалу. Отже, телесеріал здатен набувати статусу культового, але за умови, що існує стійке угрупування шанувальників, які виконують функцію зовнішньої машини, згідно з теоретичною моделлю Дельоза та Гваттарі.

Ідея множинності світу, а разом з ним його наративів, метафорично відображає концепт ризоми. Французькі постмодерністи прояснили його на прикладі традиційного медіа - книги. Серед трьох образів книги-кореню, книги-мичкуватого кореню та книги-ризоматичного кореню, Дельоз та Гваттарі наполягають, що нелінійна та непередбачувана ризома найбільше відповідає принципу множинності і стану суспільства постмодерну. Телевізійний серіал, як і книга, навряд чи просто образ світу, радше, як будь-яке медіа, множинне, ризоматичне зчеплення зі світом. Поведінка наративу телесеріалу, який є безпосередній продуктом постмодерну, яскраво ілюструє принцип ризоми перетин вимірювань в множинності, яке з необхідністю змінюється у тій мірі, в якій вона збільшує кількість своїх зв'язків. В ризомі потенційно міститься відкритість, зворотність, «вона може бути розірвана, перевернута, може пристосуватися до будь-якого монтажу» ${ }^{4}$. Так само розкриваються наративи сюжетних ходів всередині телевізійних саг: регулярні флешбеки (стрибок сюжету у минуле), флешфорвади (епізодичний перегляд сцен, що відбуваються у майбутньому головних героїв, не можна не згадати серіал «Медіум», який побудований навколо цього прийому), приховані посилання на популярні твори, культові постаті та історичні події. Навіть самі телесеріали стають «персонажами» широкоекранного кіно (великого екрану). Наприклад, такими, що мають значення для розвитку сюжету, є згадки у діалогах та показ процесу фільмування вигаданого серіалу та регулярний перегляд епізодів реального «FBI» у фільмі «Одного разу в Голівуді». Окрім кінофільмів, телевізійні шоу застосовують прийом «серіал у серіалі» тощо, як мультфільм «Чух і Сверблячка» в анімаційному серіалі «Сімпсони». Отже, в цілому телесеріал постає як ризоматичне явище культури.

Множинність проявляється у самій архітектоніці телевізійної драми. Звернемо увагу на два рівні означування у серіалі - словесний і образний, який маніфестує відеокадр. Це відомо з праць видатного семіотика і мистецтвознавця Юрія Лотмана. Хоча він писав про семіотику кіно, проте цілком обгрунтовано можна використати його міркування також щодо телевізійних серіалів. Зауваження Лотмана, що мистецька й культурна сутність аудіовізуального об'єкта обумовлюється внутрішніми протиріччями між зображувальними (іконічними) знаками фільму та умовними (символічними)

\footnotetext{
${ }^{1}$ Pearson, R. (2010) Observations on Cult Television. The Cult TV Book. London, NY, 8.

2 Делез, Ж., Гваттари, Ф. (2010). Тысяча плато: Капитализм и шизофрения. Екатеринбург: У-Фактория:

Москва: Астрель, 8.

${ }^{3}$ Дебор, Г. (2000) Общество спектакля. Москва: Логос.

${ }^{4}$ Делез, Ж., Гваттари, Ф. (2010) Тысяча плато: Капитализм и шизофрения. Екатеринбург: У-Фактория, Москва: Астрель, 22.
} 
знаками його інтерпретації ${ }^{1}$ має сутнісне значення для процесів означення статусів телесеріалів. Це протиріччя ще більш ускладнюється для телесеріалу, де текстова складова - а саме діалоги, повторні перекази подій у попередніх серіях - становить повноцінний елемент теленаративу. Іншими словами, телевізійний серіал грунтується на текстуальності двох типів знаків. Іконічні (образні) знаки, одиницею яких постає монтажний кадр або окрема сцена, створюють картинку телебачення. Умовний тип знаків (словесний) - це діалоги, голом за кадром, титри і т.д. Хоча у аудіовізуальному мистецтві цей поділ умовний, а надто у сучасному, де переважає експеримент і творчі проби, проте для нашої ідеї це розрізнення має значення. Феномен культового серіалу яскраво демонструє це протиріччя та його трансформації. Допоки технічний рівень телевізійних операторських можливостей, до яких входить i монтаж, і спеціальні ефекти, залишався досить обмеженим, всесвіт телесеріалу інтерпретувався переважно за допомогою фантазії, що опиралася не тільки на текстово-словесну складову телевізійного фільму, але й на власну ерудицію, знання та освіту глядачів.

Якщо взяти серіал «Star Trek», який у відповідній літературі вважається першим, практично «нульовим» серіалом зі статусом культового, як його назвав Лінкольн Джераті- «матір'ю всіх франшиз» ${ }^{2}$, то можна припустити, що саме високоосвічена аудиторія й складала той активний фандом, що тримав шоу у сітці мовлення. 3 часом телесеріали почали створювати під значно ширшу, але роздрібну й непостійну аудиторію. 3 розвитком технологічних можливостей телемереж, а також стратегій маркетингу, що виростали з маніпулятивної психології, у телесеріалах створювалася все більш видовищна картинка - розвивався іконічний (образний) тип знаків, який найсильніше впливає на емоційне сприйняття того чи іншого медійного послання. Сценаристи, своєю чергою, робили акцент на найбільш універсальні людські цінності: наприклад, персонажі серіалу розкривалися завдяки використанню флешбеків, які показували дитинство чи особливі події, що вплинули на характер того чи іншого героя. Навіть у таких специфічних жанрах, як наукова фантастика, акцент нині ставиться саме на людські історії, драматичні сюжети, які більш зрозумілі і прийнятні для більшої кількості глядачів. Вже не треба щось особливо вигадувати, фантазувати - все покажуть, розкажуть і у визначений час повторять. Всі ці ходи приваблювали широку аудиторію, різноманітні соціальні групи, що сприяло підвищенню рейтингів телесеріалів.

Додатково залучення аудиторії відбувалося завдяки використанню різноманітних медіа. Спеціаліст в теорії медіа та постмодерних студіях Джим Коллінз розглядає, у зв'язку з цим, трансмедіафілію. Він підкреслює, що трансмедіація, з якої розвинулася трансмедіафілія - це не просто подача однієї історії (телесеріалу) на різних інформаційних платформах чи різних медіа. Завдяки трансмедіації відбувається ніби розширення вигаданих світів (неважливо, як пише Коллінз, світу Marvel чи класичного світу Джейн Остін), створюються додаткові наративи, завдяки цьому, виникає, на його думку, особлива форма самовираження та самоідентифікації, що й проявляється не тільки у накопичуванні та зберіганні уявного всесвіту на різних цифрових пристроях, але й його розширення та своєрідна диверсифікація завдяки ризоматичним трансформаціям сюжетних наративів . Можливість розширяти всесвіти улюблених героїв утворила новітній вид цінних розваг трансмедіафілію та сприяла популяризації тих чи інших телевізійних серіалів. Хоча такі уявні персоналізовані світи відрізняються від традиційних тим, що розташовуються на декількох медіа, проте дозволяють залучати до фандому більшу кількість глядачів.

Отже, розширення аудиторії культового серіалу відбувалося за рахунок підключення більшої кількості інтерпретаційних практик завдяки нарощуванню образної потужності іконічного типу знаків та використанню різних медіа-платформ. Збільшення кількості прихильників трансформувало низку культових телесеріалів у мейнстрим. Проте такий хід має також і зворотний напрямок впливу, оскілки образні знаки діють швидко, проте так само швидко зникають. У свідомості закріплюються уподобання завдяки розумовим зусиллям, уяві та фантазії, а для цього треба мати сильну текстову умовну складову. Ті серіали, які мають дві сильні складові, мають повне право на статус як культу, так і мейнстриму аудіовізуальної культури. Таким чином, аналіз феномену телесеріалів наочно підтверджує не лише взаємовпливи масової та елітарної культури, але й тезу про те, що саме видатні витвори мистецтва, проривні відкриття науки і загалом яскраві здобутки культури закладають основи для майбутнього розвитку масової культури і забезпечують подолання регулярних духовних криз масового суспільства.

\footnotetext{
${ }^{1}$ Лотман, Ю. М. (1998). Об искусстве. Структура художественного текста. Семиотика кино и проблемы киноэстетики. Статьи. Заметки. Выступления (1962-1993). Санкт-Петергбург: Искусство-СПБ, 291-295.

${ }^{2}$ Geraghty, L. (2010). The Star Trek Franchise. The Cult TV Book. London, NY, 131.
} 


\section{References:}

1. Abbot, S. (ed.) (2010). The Cult TV Book. London, New York : I.B. Tauris. [in English].

2. Angelini, S., Booy, M. (2010). Members Only: Cult TV from Margins to Mainstream. The Cult TV Book. London, NY, 19-27. [in English].

3. Collins, J. (2017) Transmediaphilia, World Building, and Pleasures of the Personal Digital Archive. World Building. Transmedia, Fans, Industries. Amsterdam. [in English].

4. Debor, G. (2000). Obshhestvo spektaklja [Society of the Spectacle]. Moscow: Logos. [in Russian].

5. Delez, Zh., Gvattari, F. (2010). Tysjacha plato: Kapitalizm i shizofrenija [A Thousand Plateaus: Capitalism and Schizophrenia]. Ekaterinburg: U-Faktorija, Moscow: Astrel. [in Russian].

6. Fromm, E. (1999). Anatomija chelovecheskoj destruktivnosti [The Anatomy of Human Destructiveness]. Minsk: Popurri. [in Russian].

7. Geraghty, L. (2010). The Star Trek Franchise. The Cult TV Book. London, NY. [in English].

8. Hills, M. (2010). Mainstream Cult. The Cult TV Book. London, NY. [in English].

9. Horkhajmer, M., Adorno, T. (1997). Dialektika prosveshhenija: Filosofskie fragmenty [Dialectic of Enlightenment: Philosophical Fragments]. Moscow-SPb: Medium. Juventa. [in Russian].

10. Jaspers, K. (1991). Duhovnaja situacija vremeni [The spiritual situation of time]. Smysl i naznachenie istorii [The meaning and purpose of history]. Moscow: Politizdat. [in Russian].

11. Johnson, C. (2010). Cult TV and the Television Industry. The Cult TV Book. London, NY. [in English].

12. Lotman, J. M. (1998). Ob iskusstve. Struktura hudozhestvennogo teksta. Semiotika kino i problemy kinojestetiki. Stat'i. Zametki. Vystuplenija (1962-1993) [About art. The structure of the literary text. Semiotics of cinema and problems of cinema aesthetics. Articles. Notes. Speeches (1962-1993)]. SPb: Iskusstvo-SPB. [in Russian].

13. Manhejm, K. (2000). Izbrannoe. Sociologija kultury [Selected papers. Sociology of culture]. Moscow-SPb: Universitetskaja kniga. [in Russian].

14. Ortega-i-Gasset, H. (1997). Vosstanie mass [Rise of the Masses]. Ortega-i-Gasset H. Izbrannye trudy [Selected Works]. Moscow: Ves mir, 43-163. [in Russian].

15. Pearson, R. (2010). Observations on Cult Television. The Cult TV Book. London, NY. [in English].

16. Selznick, P. (1951) Institutional Vulnerability in Mass Society. American Journal of Sociology, 56, $320-331$. [in English]. 